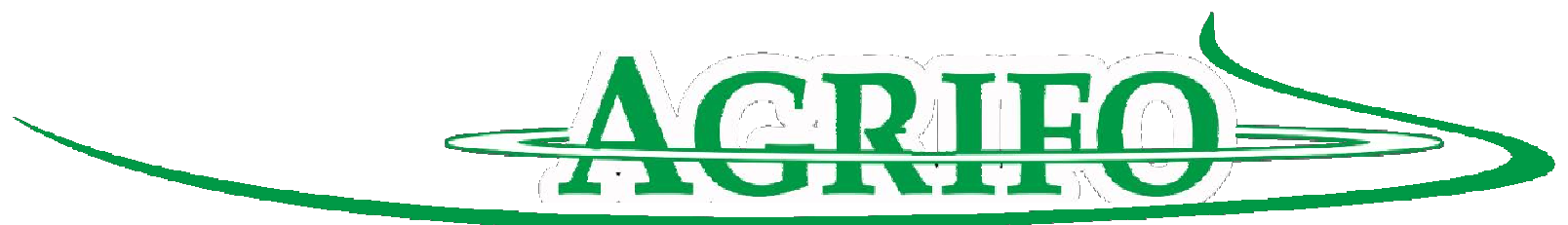

\title{
ANALISIS FAKTOR YANG MEMPENGARUHI PETANI MEMILIH POLA TANAM PADA TANAMAN PERKEBUNAN DI DESA PAYA PALAS KECAMATAN RANTO PEUREULAK KABUPATEN ACEH TIMUR
}

\author{
Nurdarmawan Syahputra ${ }^{1}$, Mawardati $^{2}$, Suryadi $^{2}$ \\ E-mail Author: nurdarmawan.sahputra@gmail.com
}

\begin{abstract}
The cropping pattern is one of the factors determining the achievement of optimal results in a farming estate, because if one chooses the type of planting pattern then the results achieved will be not optimal. This research aims to analyze the factors which influence what farmers in choosing cropping patterns on commodities existing plantation in the village of Paya Ranto Peureulak Subdistrict Palas East Aceh Regency Sampling method in this study using a Simple Random Sampling and to determine the quantity of the sample Slovin formula used. Research on data analysis using the method of Logistic regression analysis with the help of SPSS software 16.

From the results of the study indicate that there are two variables that influence significantly to decisions of farmers in choosing cropping patterns that is land area, and the distance of the location residence of farming peasants, whereas education level has no effect significant. Two other factors, namely capital, and revenue has been removed from the model due to experiencing a large correlation with the other freevariables.
\end{abstract}

Keywords: pattern of cropping, crop plantations, logistic regression

\section{PENDAHULUAN}

Pembangunan
pedesaan masih sangat banyak
menghadapi masalah, salah satu
diantaranya adalah peningkatan
produksi dan produktivitas. Peningkatan
produksi dan produktivitas ini
merupakan keharusan karena merupakan
landasan dan prasyarat bagi proses
industrialisasi. Di satu sisi, produksi
pertanian diperoleh melalui proses yang
panjang dan penuh resiko kegagalan.
Dari segi waktu, usaha perkebunan
membutuhkan waktu yang lebih panjang
dibandingkan dengan tanaman pangan
dan hortikultura.

Dalam setiap kegiatan pertanian, baik itu perkebunan, tanaman pangan, maupun hortikultura, pasti selalu menggunakan pola tanam. Pola tanam adalah usaha penanaman pada sebidang lahan dengan mengatur susunan tata letak dan tata urutan tanaman selama periode waktu tertentu, termasuk masa pengolahan tanah dan masa bera atau tidak ditanam selama periode tertentu (Campbell, 2002).

Beberapa jenis tanaman perkebunan yang sering menggunakan pola tanam polikultur yaitu kelapa, kakao, karet, dan kelapa sawit. Tanaman kelapa sebagai tanaman utama dapat dipolikulturkan dengan cengkeh, kayu

\footnotetext{
${ }^{1}$ Mahasiswa Fakultas Pertanian Universitas Malikussaleh

${ }^{2}$ Staff Pengajar Fakultas Pertanian Universitas Malikussaleh
} 
manis, lada, dan nenas (Barus, 2013). Kakao sebagai tanaman utama dapat dipolikulturkan dengan kopi, kelapa, cengkeh, pisang, dan panili. Karet sebagai tanaman utama dapat dipolikulturkan dengan tanaman tahunan yaitu padi, kedelai, jagung, semangka, nilam, kapulaga, petai, jengkol, durian, kayu dan jahe merah. Sedangkan kelapa sawit dapat dipolikulturkan dengan singkong, jagung, palawija, dan gaharu. Dari berbagai jenis tanaman yang polikulturkan dengan beberapa tanaman perkebunan tersebut memiliki berbagai keuntungan ekonomis dan juga lingkungan diantaranya dapat mengikat unsur hara tanah, dapat menjadi mulsa untuk menjaga kelembaban tanah, dan juga sebagai penghasil unsur hara (Karmawati, 2010).

Kecamatan Ranto Peureulak memiliki jumlah desa yang hampir setara dengan jumlah kecamatan yaitu berjumlah 23 desa. Desa Paya Palas merupakan salah satu desa di Kecamatan Ranto Peureulak yang memiliki perkebunan rakyat terluas dibandingkan dengan 22 desa lainnya. Hal ini tercermin dari luas lahan yang dimanfaatkan sebagai lahan perkebunan yang ada di Desa Paya Palas. Berikut ini dapat dilihat luas lahan perkebunan yang tersebar di 23 desa.

Tabel 3. Luas Lahan Perkebunan Kecamatan Ranto Peureulak tahun 2013

\begin{tabular}{|c|c|c|}
\hline No. & Desa & Luas Lahan \\
\hline 1 & Beurandang & 1.235 \\
\hline 2 & Alue Geunteng & 1.232 \\
\hline 3 & Kliet & $\overline{1.047}$ \\
\hline 4 & Tampak & 425 \\
\hline 5 & Paya Palas & 1.420 \\
\hline 6 & Alue Batee & 1.155 \\
\hline 7 & Bhom Lama & 23 \\
\hline 8 & Pasie Puteh & 57 \\
\hline 9 & Alue Dua & 153 \\
\hline 10 & Buket Pala & 59 \\
\hline 11 & Punti Payong & 1.078 \\
\hline 12 & Seumali & 288 \\
\hline 13 & Pertamina & 109 \\
\hline 14 & Blang Barom & 150 \\
\hline 15 & Pulo Blang & 118 \\
\hline 16 & Seuneubok Johan & 596 \\
\hline 17 & Paya Unou & 546 \\
\hline 18 & Seuneubok Baro & 130 \\
\hline 19 & Seuneubok Dalam & 167 \\
\hline 20 & Seuleumak Muda & 280 \\
\hline 21 & Mata Ie & 650 \\
\hline 22 & Alue Udep & 590 \\
\hline 23 & Seumeunah Jaya & 363 \\
\hline Jum & ah Luas Lahan Perkebunan & 11.871 \\
\hline
\end{tabular}

Sumber: BPS Aceh Timur (2015) 
Penduduk Desa Paya Palas yang berprofesi sebagai petani perkebunan yaitu berjumlah 589 orang, dan dari total jumlah petani perkebunan di Desa Paya Palas tersebut banyak yang menanam tanaman perkebunan lebih dari satu jenis komoditi dalam satu lahan. Namun, komoditi yang ditanam dalam satu lahan tersebut adalah sama-sama komoditi unggulan seperti karet dan kelapa sawit, kakao dan karet, kelapa sawit dan pinang, dan masih banyak yang lainnya, yang mengakibatkan persaingan antar tanaman tersebut sehingga tidak cocok dilakukan usahatani yang demikian.

Menurut Yodha dalam Permana (2007) mengatakan maksud pola tanam adalah rangkaian tanaman yang ditanam pada sebidang lahan selama kurun waktu tertentu, biasanya satu tahun. Di dalam pola tanam terkandung unsur-unsur yang kompleks, mulai dari pemilihan jenisjenis tanaman, cara bertanam, cara panen, serta apakah nantinya hasil yang diperoleh memiliki nilai pasar atau tidak.

Keuntungan pola tanam, dapat diperoleh dengan menggunakan pola tanam yang tepat, keuntungan tersebut antara lain dapat meningkatkan efisiensi penggunaan sumberdaya yang ada. Intensitas penggunaan lahan meningkat, dengan memanfaatkan sumber daya lahan dan waktu lebih efisien, meningkatkan pula produktivitas lahan (Raharja, 2005).

Secara umum ada dua jenis pola tanam yang digunakan oleh petani yaitu, monokultur dan polikultur.

\section{Monokultur}

Pertanaman tunggal atau monokultur adalah salah satu cara budidaya di lahan pertanian dengan menanam satu jenis tanaman pada satu areal. Monokultur menjadikan penggunaan lahan efisien karena memungkinkan perawatan dan pemanenan secara cepat dengan bantuan mesin pertanian dan menekan biaya tenaga kerja karena wajah lahan menjadi seragam.

Kelemahan utamanya adalah keseragaman kultivar mempercepat penyebaran organisme pengganggu tanaman (OPT, seperti hama dan penyakit tanaman), pola tanam monokultur memiliki pertumbuhan dan hasil yang lebih besar daripada pola tanam lainnya. Hal ini disebabkan karena tidak adanya persaingan antar tanaman dalam memperebutkan unsur hara maupun sinar matahari.

Setjanata

mengungkapkan tentang keunggulan dan kelemahan pola tanam monokultur. Kelebihan pola tanam ini yaitu teknis budidayanya relatif mudah karena tanaman yang ditanam maupun yang dipelihara hanya satu jenis. Namun disisi lain, kelemahan pola tanam ini adalah tanaman relatif mudah terserang hama maupun penyakit.

\section{Polikultur}

Polikultur berasal dari kata poly dan culture. Poly berarti banyak dan culture berarti pengolahan. Jadi, pola tanam polikultur adalah penanaman lebih dari satu jenis tanaman pada suatu lahan pertanian dalam waktu satu tahun. Polikultur adalah model pertanian yang menerapkan aspek lingkungan yang lebih baik dan melestarikan keanekaragaman hayati lokal. Keanekaragaman hayati yang dimaksud tidak hanya dari segi flora (tumbuhan) tetapi juga fauna yang ada (Sabirin, 2010).

Permana (2007), meneliti tentang faktor-faktor internal dan eksternal yang mempengaruhi petani dalam memilih pola tanam yang menguntungkan. Penelitian ini menggunakan metode survey dengan 123 responden yang 
dipilih secara acak berlapis dan dialokasikan secara proporsional. Analisis pengujian menggunakan regresi linear berganda, dan dari hasil penelitian ditetapan faktor-faktor yang berpengaruh terhadap petani dalam memilih pola tanam adalah: tingkat pendidikan, luas lahan garapan, status lahan, biaya tenaga kerja, biaya sarana produksi, serta jarak lokasi usahatani dengan tempat tinggal petani. Hasil pengujian menunjukkan bahwa hanya status penguasaan lahan, biaya sarana produksi, dan jarak tempuh dari rumah petani ke lokasi usahatani yang berpengaruh terhadap petani dalam memilih pola tanam yang menguntungkan.

\section{METODE PENELITIAN}

Penelitian ini dilakukan di Desa Paya Palas Kecamatan Ranto Peureulak Kabupaten Aceh Timur. Pemilihan lokasi dilakukan secara sengaja (purposive) dengan pertimbangan di desa tersebut memiliki luas lahan perkebunan yang paling luas diantara desa lain yang ada di Kecamatan Ranto Peureulak.

Ruang lingkup penelitian ini hanya dibatasi pada faktor yang mempengaruhi petani dalam memilih pola tanam (polikultur/monokultur). Objek penelitian ini yaitu petani yang menggunakan pola tanam polikultur/monokultur.

\section{Sampel Penelitian}

1. Salah satu cara menentukan besaran sampel yang memenuhi hitungan itu adalah yang dirumuskan oleh Slovin yaitu :

Keterangan :

$$
n=\frac{N}{\left(?+N e^{[}\right)}
$$

$\mathbf{n}=$ jumlah sampel
$\mathbf{N}=$ jumlah seluruh anggota populasi

e $=$ toleransi terjadinya kesalahan (Amirin, 2011)

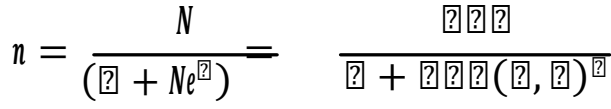

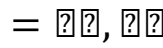

Dalam penelitian ini, peneliti menggunakan toleransi kesalahan sebesar $10 \%$, dengan menggunakan rumus di atas maka didapatkan jumlah petani sampel yang digunakan dalam penelitian ini berjumlah 85,48 sehingga peneliti memutuskan untuk membulatkan jumlah sampel menjadi 86 orang.

\section{Metode Analisis Data}

Penelitian ini menggunakan pendekatan kuantitatif dengan menggunakan analisis model regresi logit. Penggunaan model logit dalam penelitian ini dikarenakan variabel $\mathrm{Y}$ yang bersifat biner, yaitu faktor yang mempengaruhi keputusan petani memilih pola tanam pada tanaman perkebunan (polikultur/monokultur). Spesifikasi model dalam penelitian ini yaitu :

$Y=\ln \left(\frac{p i}{1-p 1}\right)=\beta_{0}+\beta_{1} X_{1}+\beta_{2} X_{2}+\beta_{3} X_{3}$ $+\beta \mathrm{X}$

$$
{ }_{4}{ }_{4}+\beta_{5} \mathrm{X}_{5}
$$

Keterangan :

$\mathrm{Y}=$ Polikultur atau Monokultur

$\beta_{0}-\beta_{5}=$ Konstanta

$\mathrm{X}_{1} \quad=$ Modal

$\mathrm{X}_{2} \quad=$ Luas lahan

$\mathrm{X}_{3} \quad=$ Pendapatan usahatani

$\mathrm{X}_{4}=$ Jarak antara tempat tinggal dengan lokasi usahatani

$\mathrm{X}_{5} \quad=$ Tingkat pendidikan

e $\quad=$ Error term

\section{Hasil dan Pembahasan}

Analisis regresi logistik biner (binominal) digunakan untuk melihat pengaruh sejumlah variabel bebas (X1, 
$\mathrm{X} 2, \mathrm{X} 3, \mathrm{X} 4, \mathrm{X} 5)$ terhadap variabel terikat (Y) yang berupa variabel biner dan hanya mempunyai dua nilai. Penelitian ini, analisis faktor-faktor yang mempengaruhi petani memilih pola tanam pada tanaman perkebunan di Desa Paya Palas Kecamatan Ranto Peureulak Kabupaten Aceh Timur dilakukan dengan menggunakan model regresi binary logistic. Dalam menentukan peluang terpilihnya salah satu kategori dari pola tanam maka salah satu dari pola tanam tersebut harus menjadi kontrol. Pada permasahan ini, petani menggunakan pola tanam polikultur dengan kombinasi jenis tanaman yang salah namun petani tetap mempertahankan pola tanam tersebut dan tidak mau untuk mengubahnya. Dalam hal ini maka pola tanam polikultur diberikan nilai 0 dan pola tanam monokultur diberikan nilai 1 . Jumlah data yang digunakan dalam penelitian ini sebanyak 86 .

\section{Analisis Metode Logit Overall Test/Uji G (Chisquare)}

Uji G (Chisquare) dilakukan untuk menguji tingkat signifikansi suatu model dalam penelitian. Hasil analisis Uji $G$ dapat dilihat pada tabel di bawah ini.

Tabel 10. Omnibus Tests of Model Coefficients

\begin{tabular}{llllll} 
& \multicolumn{2}{c}{ Chi-square } & df & \multicolumn{2}{c}{ Sig. } \\
\hline Step 1 & Step & 44.311 & 3 & .000 \\
\cline { 2 - 5 } & Block & 44.311 & 3 & .000 \\
\cline { 2 - 5 } & Model & 44.311 & 3 & .000 \\
\hline
\end{tabular}

Ujian $G$ bagi model koefisien menunjukkan bahwa uji statistik $\chi^{2}$ adalah untuk menguji Ho, dimana semua hubungan dan koefisien ekpektasi sama dengan nol adalah $\chi^{2}=44,311$ dengan derajat kebebasan adalah 3 dan nilai sig $=0,000$. Hal ini menunjukkan bahwa regresi logistik sangat signifikan. Variabel dependen berkaitan dengan setiap variabel independen dan keseluruhan model sangat signifikan secara statistik, meskipun ia tidak menggambarkan keseluruhan bagi setiap variabel yang dikaji. Dapat disimpulkan bahwa variabel bebas yang digunakan dalam model secara bersamaan berpengaruh terhadap pemilihan pola tanam oleh petani pada tanaman perkebunannya.

\section{Uji Multikolinieritas}

Pada model regresi logistik, satusatunya asumsi yang harus dipenuhi adalah distribusi normal pada error dan hasil estimasi. Syarat tersebut tidak memerlukan pengujian khusus dan hampir selalu terpenuhi pada semua jenis data. Meskipun begitu, tetap perlu dilakukan pengujian multikolinearitas untuk mengetahui apakah ada korelasi yang kuat antara variabel independen pada model ini.

Pada pengujian pertama yang dilakukan, peneliti mendapatkan hasil yang kurang baik yaitu terdapat korelasi yang cukup besar antara variabel modal dengan luas lahan dan variabel luas lahan dengan pendapatan, untuk lebih jelasnya dapat dilihat pada tabel berikut ini. 
Tabel 14. Matriks Korelasi sebelum dilakukan analisis perbaikan

\begin{tabular}{llrrrrrr} 
& & Constant & $\mathrm{X} 1$ & $\mathrm{X} 2$ & $\mathrm{X} 3$ & $\mathrm{X} 4$ & $\mathrm{X}$ \\
\hline \multirow{2}{*}{ Step 1 } & Constant & 1.000 & -.647 & .684 & -.618 & .001 & -.098 \\
\cline { 2 - 7 } & $\mathrm{X} 1$ & -.647 & 1.000 & -.897 & .588 & -.433 & -.455 \\
\cline { 2 - 7 } $\mathrm{X} 2$ & .684 & -.897 & 1.000 & -.845 & .358 & .492 \\
\cline { 2 - 7 } $\mathrm{X} 3$ & -.618 & .588 & -.845 & 1.000 & -.390 & -.530 \\
\cline { 2 - 7 } & .001 & -.433 & .358 & -.390 & 1.000 & .538 \\
\cline { 2 - 7 } & $\mathrm{X} 4$ & -.098 & -.455 & .492 & -.530 & .538 & 1.000
\end{tabular}

Kemudian dilakukan analisis perbaikan memasukkan variabel pendapatan dalam untuk menghilangkan korelasi antar variabel bebas dengan mengeluarkan penelitian dan didapatkan hasil korelasi variabel modal (X1) namun tetap antar variable bebas yang semakin besar.

Tabel 15. Matriks Korelasi dengan Mengeluarkan Modal

\begin{tabular}{|c|c|c|c|c|c|c|}
\hline \multirow{2}{*}{$\overline{\text { Step } 1}$} & & Constant & $\mathrm{X} 2$ & X3 & $\mathrm{X} 4$ & $\overline{X 5}$ \\
\hline & Constant & 1.000. & .521 & -.567. & -.169 & -.549 \\
\hline & $\mathrm{X} 2$ & .521 & 1.000 & -.919 & .001 & .081 \\
\hline & $\mathrm{X} 3$ & -.567 & -.919 & 1.000 & -.234 & -.208 \\
\hline & $\mathrm{X} 4$ & -.169 & .001 & -.234 & 1.000 & .207 \\
\hline & $\mathrm{X} 5$ & -.549 & .081 & -.208 & .207 & 1.000 \\
\hline \multicolumn{4}{|c|}{$\begin{array}{l}\text { Karena hasil korelasinya semakin besar } \\
\text { yaitu nilai korelasinya hampir mendekati } \\
1 \text { maka dilakukan pengujian kembali } \\
\text { dengan mengeluarkan variabel }\end{array}$} & \multicolumn{3}{|c|}{$\begin{array}{lr}\text { pendapatan }(\mathrm{X} 3) \text { dan memasukkan } \\
\text { variabel modal, hasil yang didapatkan } \\
\text { tidak jauh berbeda } \\
\text { mengeluarkan }\end{array}$} \\
\hline
\end{tabular}

Tabel 16. Matriks Korelasi dengan Mengeluarkan Pendapatan

\begin{tabular}{clrr} 
& & Constant & X1 \\
\cline { 2 - 3 } Step 1 & Constant & 1.000 & -.459 \\
\cline { 2 - 3 } & X1 & -.459 & 1.000 \\
\cline { 2 - 3 } X2 & .381 & -.917 \\
X4 & -.251 & -.324 \\
\cline { 2 - 3 } & X5 & -.624 & -.208 \\
\hline
\end{tabular}

Setelah dikeluarkan variabel pendapatan (X3) juga masih tetap mengalami korelasi yang tinggi, maka pada

\begin{tabular}{rrr}
$\mathrm{X} 2$ & $\mathrm{X} 4$ & $\mathrm{X} 5$ \\
\cline { 3 - 3 } .381 & -.251 & -.624 \\
-.917 & -.324 & -.208 \\
1.000 & .138 & .108 \\
.138 & 1.000 & .288 \\
.108 & .288 & 1.000
\end{tabular}

pengujian selanjutnya dilakukan dengan mengeluarkan variabel modal (X1) dan variabel pendapatan (X3), dan 
didapatkan hasil yang sangat baik yaitu tidak terjadi korelasi antar variabel bebas. Output dari pengujian terakhir multikolinearitas pada penelitian ini dapat dilihat pada tabel di bawah ini.

Tabel 17. Matriks Korelasi

\begin{tabular}{llrrrr}
\hline & & \multicolumn{1}{c}{ Constant } & \multicolumn{2}{c}{ X2 } & \multicolumn{2}{c}{ X4 } & \multicolumn{2}{c}{ X5 } \\
\hline Step 1 & Constant & 1.000 & -.049 & -.362 & -.816 \\
\cline { 2 - 6 } & $\mathrm{X} 2$ & -.049 & 1.000 & -.539 & -.232 \\
\cline { 2 - 6 } X4 & -.362 & -.539 & 1.000 & .115 \\
\cline { 2 - 6 } X5 & -.816 & -.232 & .115 & 1.000 \\
\hline
\end{tabular}

Pada pengujian multikolinearitas, indikasi adanya korelasi yang kuat antar variabel independen ditunjukkan dengan angka korelasi yang melebihi 0,8 . Hasil penelitian menunjukkan bahwa tidak ada angka korelasi antar variabel independen yang melebihi 0,8 , sehingga dapat disimpulkan tidak terdapat masalah multikolinearitas pada variabel-variabel independen dalam model.

\section{Analisis Metode Logit Partial Test/Uji Wald}

Pada model logistik atau logit, Uji parsial diharapkan bisa menolak $\mathrm{H}_{\mathrm{o}}$ sehingga variabel yang sedang di uji bisa masuk ke dalam model. Jika didapatkan nilai sig $<\alpha$ maka $\mathrm{H}_{\mathrm{o}}$ di tolak dan jika nilai sig $>\alpha$ maka $\mathrm{H}_{\mathrm{o}}$ diterima. Hasil analisis Uji Wald atau uji parsial dapat dilihat pada Tabel 18.

Tabel 18. Uji Wald

\begin{tabular}{lllrlrrrr}
\hline & & B & S.E. & Wald & df & \multicolumn{1}{c}{ Sig. } & \multicolumn{1}{c}{ Exp(B) } \\
\hline Step 1 & a & X2 & 1.397 & .360 & 15.090 & 1 & .000 & 4.043 \\
\cline { 2 - 9 } & X4 & -.698 & .204 & 11.689 & 1 & .001 & .498 \\
\cline { 2 - 9 } & X5 & -.071 & .112 & .407 & 1 & .524 & .931 \\
\cline { 2 - 8 } & Constant & .160 & 1.255 & .016 & 1 & .899 & 1.173 \\
\hline
\end{tabular}

a. Variable(s) entered on step 1: X2, X4, X5.

Dari tabel di atas terlihat bahwa variabel bebas yang berpengaruh secara signifikan terhadap pemilihan pola tanam petani yaitu luas lahan dan jarak tempat tinggal petani dengan lokasi usahatani, sedangkan variabel tingkat pendidikan tidak berpengaruh secara signifikan. Variabel-variabel yang mempengaruhi petani dalam memilih pola tanam pada tanaman perkebunan adalah luas lahan $(0,000<0,10)$, jarak lokasi usahatani dengan tempat tinggal petani $(0,001<0,10)$.

Hasil analisis di atas merupakan hasil analisis kedua atau analisis perbaikan dengan mengeluarkan variabel modal dan pendapatan. Pada analisis sebelumnya didapatkan bahwa nilai $\beta$ dari variabel modal dan pendapatan yaitu bernilai 0,000 (lihat lampiran 4) dan juga nilai koefisien bernilai negatif yaitu $-7,019$ (lihat lampiran 4) sehingga kurang bagus 
untuk model penelitian, maka diputuskan untuk mengeluarkan varabel modal dan pendapatan agar hasil analisis menjadi lebih baik lagi.

Setelah dilakukan analisis kedua atau analisis perbaikan pada model regresi logistik maka selanjutnya didapatkan persamaan model logit dalam penelitian ini adalah sebagai berikut:

$\mathrm{Y}=0,160+1,397 \mathrm{X} 2-0,698 \mathrm{X} 4-$ $0,071 X 5$

Hasil analisis menunjukan bahwa nilai koefisien estimasi dari variabel luas lahan (X2) berpengaruh positif dengan pemilihan pola tanam. Hal ini menunjukkan bahwa semakin luas lahan yang dimiliki oleh petani maka petani tersebut akan memilih pola tanam monokultur, hal ini bermakna bahwa peningkatan luas lahan sebesar $1 \mathrm{Ha}$ yang dimiliki oleh petani maka akan meningkatkan kemungkinan petani memilih pola tanam monokultur sebesar 1,397, dengan asumsi semua faktor lain dianggap tetap. Estimasi probabilitas menunjukkan bahwa semakin luas lahan yang dimiliki oleh petani, maka petani tersebut mempunyai peluang sebesar 4,043 kali untuk memilih pola tanam monokultur dibandingkan petani yang mempunyai luas lahan sempit.

Hal ini sesuai dengan pendapat dari Setjanata (1983), beliau mengatakan bahwa pola tanam monokultur lebih mudah dalam teknis budidayanya, karena tanaman yang ditanam maupun yang dipelihara hanya satu jenis dan juga jumlah produksi yang lebih besar daripada pola tanam lainnya, jumlah produksi yang lebih besar ini disebabkan oleh jumlah tanaman yang dapat ditanam dalam per hektarnya dibandingkan dengan pola tanam yang lainnya.

Dalam model penelitian ini diperoleh nilai variabel jarak lokasi usahatani dengan tempat tinggal petani (X4) mempunyai pengaruh yang negatif terhadap pemilihan pola tanam, hal ini menunjukkan bahwa semakin jauh jarak lokasi usahatani maka akan membuat petani tersebut lebih memilih jenis pola tanam yang bisa menghasilkan lebih banyak komoditi. Ini bermakna akan menurunkan peluang petani untuk memilih pola tanam monokultur. Dapat disimpulkan yang bahwa semakin jauh 1 $\mathrm{Km}$ lokasi usahatani dengan tempat tinggal petani maka akan mengurangi peluang petani memilih pola tanam monokultur sebesar 0,698, dengan asumsi semua faktor lain dianggap tetap. Estimasi probabilitas menunjukkan bahwa petani yang melakukan usahataninya jauh dari tempat tinggal mempunyai peluang 0,498 kali untuk tidak memilih pola tanam monokultur dibandingkan petani yang melakukan usahataninya dekat dengan tempat tinggalnya.

Perilaku seperti ini dianggap wajar karena lokasi usahatani yang jauh akan memerlukan waktu yang lama dalam menempuhnya dan juga tambahan biaya untuk mobilisasi dari rumah menuju ke lokasi usahatani, sehingga petani lebih memilih untuk mendiversifikasikan jenis tanaman yang ditanam dibandingkan dengan hanya menanam satu jenis komoditi saja pada lahan yang jauh. Petani yang memiliki lokasi usahatani yang jauh maka akan memaksimalkan kinerjanya dilokasi usahatani berlangsung dibandingkan harus menghabiskan waktu untuk menempuh perjalanan yang jauh, namun saat sampai dilokasi usahatani hanya sedikit pekerjaan yang ia lakukan.

Pendidikan merupakan suatu media untuk memperoleh pengetahuan. Semakin tinggi tingkat pendidikan petani, diharapkan petani tersebut mampu mengetahui bagaimana cara 
memilih komoditi yang tepat pada saat memilih pola tanam. Berdasarkan hasil pengujian dari penelitian ini, didapatkan tingkat signifikan variabel tingkat pendidikan (X5) lebih besar daripada nilai $\alpha$ sehingga variabel tingkat pendidikan tidak berpengaruh signifikan terhadap pemilihan pola tanam, hal ini disebabkan karena banyak petani yang memiliki tingkat pendidikan yang tinggi namun tetap saja memilih untuk menggunakan pola tanam polikultur dibandingkan dengan pola tanam monokultur, padahal seperti yang diungkapkan oleh para ahli bahwa pola tanam monokultur mampu menghasilkan produksi yang lebih tinggi dibandingkan dengan pola tanam yang lain.

Hasil penelitian ini juga sejalan dengan hasil penelitian yang didapatkan oleh Permana (2007), beliau mendapatkan bahwa tingkat pendidikan belum menunjukkan pengaruhnya terhadap pemilihan jenis pola tanam karena tingkat pendidikan petani dilokasi penelitiannya kurang bervariasi atau cenderung beragam sehingga kurang menunjukkan pengaruh tingkat pendidikan terhadap pemilihan pola tanam.

\section{KESIMPULAN}

Berdasarkan hasil penelitian
yang telah dilakukan dengan menggunakan analisis regresi logistik dapat disimpulkan bahwa faktor-faktor yang mempengaruhi petani dalam memilih pola tanam pada tanaman perkebunan di Desa Paya Palas Kecamatan Ranto Peureulak Kabupaten Aceh Timur dipengaruhi oleh tiga faktor yaitu luas lahan, jarak lokasi usahatani dengan tempat tinggal petani, dan tingkat pendidikan yang ditempuh oleh petani. Sedangkan dua faktor lagi yaitu modal, dan pendapatan tidak mempengaruhi petani dalam memilih pola tanam.

\section{Saran}

1. Bagi petani, diharapkan dalam memilih pola tanam polikultur lebih memperhatikan jenis-jenis tanaman yang sesuai dan bisa dikombinasikan sehingga tidak merugikan tanaman yang lainnya.

2. Bagi pemerintah, diharapkan bisa memberikan pelatihan dan memberikan pengetahuan kepada petani perkebunan tentang pemilihan jenis komoditi yang sesuai untuk jenis pola tanam polikultur sehingga petani tidak mengalami kerugian akibat salah memilih jenis komoditi yang akan ditanam.

\section{DAFTAR PUSTAKA}

Amirin, T.M. 2011. "Populasi dan sampel penelitian 4: Ukuran sampel rumus Slovin." Tatangmanguny.wordpress.co m. [Di akses pada 27 Maret 2016]

Barus, J. 2013. Pemanfaatan Lahan di bawah Tegakan Kelapa di Lampung. Balai Pengkajian Teknologi Pertanian Lampung. Vol. 2, No.1: 6874, April 2013.

Campbell, V.A. 2002. Biology. Jakarta: Erlangga.

Gujarati, D. 2003. Ekonometri Dasar. Terjemahan: Sumarno Zain, Jakarta: Erlangga.

Karmawati, Elna, Zainal M, Syakir M, Joni M, Ketut A, dan Rubiyo. 2010. Budidaya \& Pasca Panen KAKAO. Pusat 
Penelitian dan Pengembangan Perkebunan, Balai Penelitian dan Pengembangan Pertanian.

Raharja dan Wiryanto, W. 2005. Diktat Dasar-dasar Agronomi. Fakultas Pertanian Universitas Brawijaya, Malang.

Sabirin. 2010. Modul Sekolah Lapang Polikultur. BITRA Indonesia. Medan.
Setjanata, S. 1983. Perkembangan Penerapan Pola Tanam dan Pola Usahatani dalam Usaha Intensifikasi.

Permana, S.N. 2007. Faktor-faktor Internal dan Eksternal yang Mempengaruhi Petani dalam Memilih Pola Tanam Yang Menguntungkan. Wawasan TRIDHARMA No. 2 Tahun XX September 2007. 